\section{Allelopathy of Bermudagrass, Tall Fescue, Redroot Pigweed, and Cutleaf Evening Primrose on Pecan}

\author{
Michael W. Smith', Margaret E. Wolf ${ }^{2}$, Becky S. Cheary ${ }^{3}$, and \\ Becky L. Carroll ${ }^{3}$ \\ Department of Horticulture and Landscape Architecture, Oklahoma State \\ University, Stillwater, OK 74078
}

Additional index words. Carya illinoinensis, Cydon dactylon, Festuca arundinacea, Amaranthus retroflexus, Oenothera laciniata

\begin{abstract}
Two studies were conducted to determine if selected grass and dicot species had an allelopathic interaction with pecan (Carya illinoinensis Wangenh. C. Koch). Leachate from pots with established grasses or dicots was used to irrigate container-grown pecan trees. Leachates from bermudagrass [Cynodon dactylon (L.) Pers.], tall fescue (Festuca arundinacea Shreb. cv. Kentucky 31), redroot pigweed (Amaranthus retroflexus L.), and cutleaf evening primrose (Oenothera laciniata Hill) reduced leaf area and leaf dry weight about $20 \%$ compared to the controls. Bermudagrass, tall fescue, and primrose leachate decreased pecan root weight $17 \%$, trunk weight $22 \%$, and total tree dry weight $19 \%$ compared to the control. In a second study, trees were $10 \%$ shorter than the control when irrigated with bermudagrass or pigweed leachate.
\end{abstract}

Weed interference (competition + allelopathy) is detrimental to growth of young pecan trees (Foshee et al., 1995; Norton and Storey, 1970; Patterson and Goff, 1994; Patterson et al., 1990; Wolf and Smith, 1999). Weed interference can also dramatically reduce pecan yield (Foshee et al., 1997; Hunter, 1950). It has been generally assumed that the growth or yield reductions observed were primarily due to competition for water and nutrients; however, Wolf and Smith (1999) demonstrated that one weed growing in close proximity to a young pecan tree was sufficient to cause a substantial growth reduction with little effect on water or nutrient availability. Typical field studies cannot separate the effects of competition from allelopathy since they happen simultaneously. Artificial environments must be devised that remove any possibility of competition while allowing chemical exchange to take place.

Chemical inhibition of growth by one plant upon another has been demonstrated among several species (Rice, 1995). The compounds causing the growth inhibition are typically organic acids or phenolic compounds, but occasionally other compounds are identified.

We chose four species to test for their allelopathic interaction with pecan; tall fescue, bermudagrass, redroot pigweed, and cutleaf evening primrose. Both tall fescue and bermudagrass are commonly used ground cov-

\footnotetext{
Received for publication 16 Jan. 2001. Accepted for publication 2 Mar. 2001. Approved for publication by the Oklahoma Agriculture Experiment Station, Stillwater, OK. The cost of publishing this paper was defrayed in part by the payment of page charges. Under postal regulations, this paper therefore must be hereby marked advertisement solely to indicate this fact.

${ }^{1}$ Regents Professor.

${ }^{2}$ Graduate Research Assistant.

${ }^{3}$ Research Assistants.
}

tainers with pigweed, bermudagrass, or no plant were placed in funnels on an elevated bench. A flexible tube was connected to the funnel that directed water to the pecan tree below, similar to the apparatus described by Walters and Gilmore (1976), except fresh water was used for each irrigation rather than recirculating the water. All irrigation water applied to the pecan trees for the 4-month treatment period was from the elevated containers. Each treatment contained 10 single-tree replications in a randomized complete-block design. The experiment was conducted in a greenhouse with an average $33{ }^{\circ} \mathrm{C}$ day/ $18{ }^{\circ} \mathrm{C}$ night temperature and the day length was adjusted to $12 \mathrm{~h}$ with incandescent lights.

After 4 months, leaves were removed and area measured with a LI-COR area meter (LI-COR, Lincoln. Nebr.). Trunk diameter was measured $2.5 \mathrm{~cm}$ above the soil line, and seedling height was measured from the soil line to the terminal bud. Leaves and roots were dried at $70{ }^{\circ} \mathrm{C}$ until constant weight, then weighed. Data were analyzed by analysis of variance (ANOVA) and orthogonal contrasts were used to compare treatments.

Expt. 2. The second study determined the effects of leachate from bermudagrass, tall fescue, and cutleaf evening primrose on growth of seedling pecan trees. This study was conducted outside under $30 \%$ shade cloth. Fescue seed, bermudagrass rhizomes, and field-grown cutleaf evening primrose plants (rosette stage) were planted in $15-\mathrm{cm}$ diameter $\times 23-\mathrm{cm}$ deep pots filled with MetroMix 300 (Scotts Co., Marysville, Ohio) on 20 Apr. 2000. 'Giles' pecan seeds were germinated in water (Smith et al., 1997), then planted, one seed/pot, in 10 $\times 10 \times 35-\mathrm{cm}$ pots filled with the same media. Treatments were initiated on 30 May 2000, after the pecan seedlings had emerged. Plants were arranged to allow all leachate from the elevated containers to irrigate the pecan seedlings (described above). Each treatment contained 16 single-tree replications in a completely randomized design.

The pecan seedlings, grasses, dicots and control containers were fertilized monthly with $13 \mathrm{~g} /$ pot Osmocote $14 \mathrm{~N}-6 \mathrm{P}-11.6 \mathrm{~K}$ and at $45-$ $\mathrm{d}$ intervals with soluble trace element mix at $45 \mathrm{mg} \cdot \mathrm{L}^{-1}$ until the solution drained through the pot. Zinc was applied as a foliar spray until run-off at 2-week intervals using $3.6 \mathrm{~g} \cdot \mathrm{L}^{-1}$ of $36 \% \mathrm{ZnSO}_{4}$.

The experiment was terminated on 1 Sept. 2000, and data were collected as described in Expt. 1. Data were analyzed by ANOVA with appropriate comparisons using orthogonal contrasts.

\section{Results and Discussion} (Grace-Sierra International, Milpitas, Calif.) and at 45-d intervals with soluble trace element mix applied at $60 \mathrm{mg} \cdot \mathrm{L}^{-1}$ (S.T.E.M.; Peters Plant Products, Marysville, Ohio) until the solution drained through the pot. Plants were transplanted $\approx 2$ weeks before the experiment was initiated.

Treatments were pecan trees irrigated with leachate from containers of pigweed, bermudagrass, or a control with no plant. Con-
Expt. 1. Leachate from bermudagrass or pigweed suppressed tree height by $10 \%$, and leaf area and leaf dry weight were reduced $\approx 20 \%$ compared to the control (Table 1 ). Trunk diameter and root dry weight were not affected by the treatments. There were no differences between leachate from pigweed or bermudagrass affecting the pecan growth parameters we measured. 
Table 1. Expt. 1. The effect of leachate from bermudagrass or redroot pigweed on pecan tree growth.

\begin{tabular}{|c|c|c|c|c|c|}
\hline Treatment & $\begin{array}{l}\text { Tree height } \\
(\mathrm{cm})\end{array}$ & $\begin{array}{l}\text { Trunk diam } \\
(\mathrm{mm})\end{array}$ & $\begin{array}{l}\text { Leaf area } \\
\left(\mathrm{cm}^{2}\right)\end{array}$ & $\begin{array}{l}\text { Leaf dry wt } \\
(\mathrm{g})\end{array}$ & $\begin{array}{c}\text { Root dry wt } \\
\text { (g) }\end{array}$ \\
\hline Control & 40 & 6.7 & 1227 & 7.5 & 23.1 \\
\hline Bermudagrass & 36 & 7.1 & 1009 & 6.0 & 27.0 \\
\hline Redroot pigweed & 36 & 7.2 & 967 & 6.0 & 26.1 \\
\hline \multicolumn{6}{|l|}{ Contrasts } \\
\hline Control vs. other & $*$ & NS & $*$ & $*$ & NS \\
\hline Bermudagrass vs. pigweed & NS & NS & NS & NS & NS \\
\hline
\end{tabular}

Ns, ${ }^{*}$ Nonsignificant or significant at $5 \%$.

Table 2. Expt. 2. The effect of leachate from bermudagrass, tall fescue, and cutleaf evening primrose on pecan tree growth.

\begin{tabular}{|c|c|c|c|c|c|c|c|}
\hline \multirow[b]{2}{*}{ Treatment } & \multirow{2}{*}{$\begin{array}{c}\text { Tree } \\
\text { height } \\
(\mathrm{mm})\end{array}$} & \multirow{2}{*}{$\begin{array}{l}\text { Trunk } \\
\text { diam } \\
(\mathrm{mm})\end{array}$} & \multirow{2}{*}{$\begin{array}{l}\text { Leaf } \\
\text { area } \\
\left(\mathrm{cm}^{2}\right)\end{array}$} & \multicolumn{4}{|c|}{ Dry wt $(\mathrm{g})$} \\
\hline & & & & Leaf & Trunk & Root & Total seedling \\
\hline Control & 242 & 6.8 & 1247 & 10.8 & 3.0 & 17.5 & 31.3 \\
\hline Bermudagrass & 219 & 6.1 & 1110 & 9.1 & 2.4 & 15.0 & 26.4 \\
\hline Tall fescue & 231 & 5.9 & 967 & 8.9 & 2.4 & 15.0 & 26.2 \\
\hline Cutleaf evening primrose & 217 & 5.9 & 887 & 7.8 & 2.2 & 13.8 & 23.9 \\
\hline \multicolumn{8}{|l|}{ Contrasts } \\
\hline Control vs. other & NS & $* *$ & $*$ & $*$ & $*$ & $*$ & $*$ \\
\hline Grass vs. dicot & NS & NS & NS & NS & NS & NS & NS \\
\hline Bermudagrass vs. tall fescue & NS & NS & NS & NS & NS & NS & NS \\
\hline
\end{tabular}

ss, ${ }^{*}, *$ Nonsignificant or significant at $5 \%$ and $1 \%$, respectively.

In other studies, bermudagrass residue reduced dry weight of several annual vegetable and agronomic crops (Meissner et al. 1989). Bermudagrass residue also reduced radicle growth of barley (Hordeum vulgare L.), mustard (Brassica juncea L. Czern. and Coss.) and wheat (Triticum aestivum L.) (Friedman and Horowitz, 1970). Redroot pigweed water extracts reduced germination and growth of sorghum [Sorghum bicolor (L.) Moench] and cotton (Gossypium hirsutum L.) (Munger et al., 1984). In fact, cotton phytotoxicity occurred in pigweed treated soil at concentrations several fold less than the potential typical field concentrations. Palmer amaranth (Amaranthus palmeri S. Wats.), a member of the pigweed family, residues inhibited carrot (Daucus carota L.) growth by $49 \%$ and onion (Allium cepa $\mathrm{L}$.) by $68 \%$ (Menges, 1987). His data indicated that phytotoxicity from field incorporated residues of Palmer amaranth persisted from 11 to 16 weeks.

Bermudagrass and pigweed compete for nutrients and water, and in some cases light, when growing with the cultivated crop. Growth reductions observed in young pecan trees with pigweed in close proximity to the tree were greater than could be explained by water and nutrient competition (Wolf and Smith, 1999). Bermudagrass also appears to reduce pecan growth more than can be explained by competition (Smith, unpublished data). This data and that of others suggests that a significant portion of the growth reduction observed under field conditions should be attributed to allelopathy. indicate that both bermudagrass and fescue allowed to grow next to the tree severely reduce growth, but fescue appears to be more detrimental than bermudagrass. However, studies that are in progress indicate that a sufficient weed-free zone can mitigate the negative effects of either species. This is the first report that we are aware of suggesting that cutleaf evening primrose is allelopathic. This conclusion supports earlier research suggesting that the pecan growth reductions observed when cutleaf evening primrose was present exceeded that attributable to competition (Wolf and Smith. 1999).

\section{Literature Cited}

Fales, S.L. and R.C. Wakefield. 1981. Effects of turfgrass on the establishment of woody plants. Agron. J. 73:605-610.

Foshee, W.G., W.D. Goff, M.G. Patterson, and D.M. Ball. 1995. Orchard floor crops reduce growth of young pecan trees. HortScience 30:979-980.

Foshee, W.G., III, R. W. Goodman, M.G. Patterson, W.D Goff, and W.A. Dozier, Jr. 1997. Weed control increases yield and economic returns from young 'Desirable' pecan trees. J. Amer. Soc. Hort. Sci. 122:588-593.

Friedman, T. and M. Horowitz. 1970. Phytotoxicity of subterranean residues of three perennial weeds. Weed Res. 10:382-385.

Expt. 2. Leachate from bermudagrass, tall fescue, or cutleaf evening primrose reduced pecan trunk diameter $12 \%$, leaf area $21 \%$, leaf dry weight $20 \%$, trunk dry weight $22 \%$, root dry weight $17 \%$, and total tree dry weight $19 \%$ compared to the control (Table 2). The two grass species did not affect the pecan growth parameters differently than cutleaf evening primrose. There were also no differences in pecan growth between leachates derived from bermudagrass or tall fescue.

Tall fescue interfering (grown in the same pot) with sweetgum (Liquidambar styraciflura L.) reduced plant dry weight $28 \%$ after 2 month and $95 \%$ after 4 months compared to a fescue free control (Walters and Gilmore, 1976). They also found that sweetgum dry weights were reduced $19 \%$ by leachate from living fescue after $30 \mathrm{~d}$, and the leachate from dead fescue leaves reduced sweetgum dry weight by $60 \%$ during the same period. Similarly, leachates from red fescue (Festuca rubra L.) reduced growth of forsythia (Forsythia intermedia Spaeth.) (Fales and Wakefield, 1981). Tall fescue appears to be particularly competitive and have substantial chemical defenses that reduce growth of other plants. Field grown black walnuts (Juglans nigra L.) were $75 \%$ taller with $196 \%$ larger trunks after 2 years when grown in a mixed ground cover consisting of $70 \%$ forbs, $20 \%$ grasses, and $10 \%$ brambles and woody vegetation compared to a solid tall fescue sod (Todhunter and Beineke, 1979).

This data and that of others indicate that tall fescue is allelopathic and exceptionally competitive. Observations in young pecan orchards
Hunter, J.H. 1950. Some interrelationships of cultural practices, fertilization, and the production of quality pecan nuts. Proc. Southeastern Pecan Growers' Assn. 43:78-86.

Meissner, R., P.C. Nel, and E.A. Beyers. 1989. Allelopathic effect of Cynodon dactylon-infested soil on early growth of certain crop species. Applied Plant Sci. 3:125-126. amaranth (Amaranthus palmeri) and other plant residues in soil. Weed Sci. 35:339-347.

Munger, P.H., J.R. Abernathy, and J.R. Gipson 1984. The influence of selected plant residues on cotton and sorghum establishment. Proc. Southern Weed Sci. Soc. 37:320.

Norton, J.A. and J.B. Storey. 1970. Effect of herbicides on weed control and growth of pecan trees. Weed Sci. 18:522-524.

Patterson, M.G. and W.D. Goff. 1994. Effects of weed control and irrigation on pecan (Carya illinoinensis) growth and yield. Weed Tech. 8:717-719.

Patterson, M.G., G. Wehtje, and W.D. Goff. 1990. Effects of weed control and irrigation on the growth of young pecans. Weed Tech. 4:892-894.

Rice, E.L. 1995. Biological control of weeds and plant pests. Univ. of Okla. Press, Norman, Okla.

Smith, M.W., B.S. Cheary, and B.L. Carroll. 1997. Effect of water bath temperature and stratification on germination of pecan seed. HortScience 32:1272-1273.

Todhunter, M.N. and W.F. Beineke. 1979. Effect of fescue on black walnut growth. Tree Planters' Notes 30(3):20-23.

Walters, D.T. and A.R. Gilmore. 1976. Allelopathic effects of fescue on the growth of sweetgum. J. Chem. Ecol. 2:469-479.

Wolf, M.E. and M.W. Smith. 1999. Cutleaf evening primrose and Palmer amaranth reduce growth of nonbearing pecan trees. HortScience 34:10821084.
Menges, R.M. 1987. Allelopathic effects of Palmer 